\title{
Essence of Marx's Cultural Thought and Its Enlightenment to China's Cultural Industry
}

\author{
Hongxia Sun \\ Qilu Normal University (China Shandong250000)
}

\begin{abstract}
Keywords: Marx's cultural thought; Cultural industry; Enlightenment
\end{abstract}
\begin{abstract}
Since the reform and opening of our country, the improvement of material life level makes people have a higher demand for spiritual culture, which makes the development of the cultural industry has become one of the important tasks of China's socialist construction, but also allow people to effectively combine strategy began to explore the development of cultural industry and the cultural thought of Marx. The essence of Marx's cultural thoughts are elaborated, analysis of Marx's view of culture and its connotation embodied. At the same time, by combining the essence of Marx's cultural thoughts on China's cultural industry development strategy analysis hoping to make some contribution to China's cultural industry development.

Since the reform and opening up and China's rapid development of the culture industry, and formed a relatively complete system of cultural industries; however, relatively mature in western developed countries, the impact of the cultural industry, and cultural exchanges in the world on the concept of development value of China's cultural industry makes the development of Chinese cultural industry that is also facing many aspects the challenge, which makes the culture industry of our country construction theory thinking have important significance quite. But Marx's thought and culture in China after the founding of the cultural thought of Marx's inheritance and development, because of its close contact with the situation of our country, and it also has a strong theoretical significance, and combined with the content of Marx's cultural thought on the development of China's cultural industry to explore that will become a key issue in our next stage.
\end{abstract}

\section{Part One the Essence of Marx's Cultural Thought}

\section{Marx's Understanding of the Essence of Culture}

The theoretical premise of Marx's view of culture comes from the actual work of human beings and the exploration of practice, and the essence of culture is clearly defined in the process of human practice. Marx holds that human and animal production activities are essentially different: animal production activities only for themselves (or blood individuals) directly, and the production of human activities are to meet basic human needs of the self conscious of the objective world in the creation of the person itself, the purpose and ideas presented in vector form of human products, and this is the generalized form of material culture. Therefore, Marx's cultural thought holds that culture is a carrier of will, an organic unity of two activities of human transformation of the world and self transformation, and the development of human culture should be closely related to personal and material production time. In other words, the development of culture can guide the development of material and objective existence, and the existence of matter can guide the progress of spiritual culture. The two are closely related and constitute the internal driving force for the development of human society and the progress of civilization.

\section{The Chinese Practice of Marx's Cultural Theory}

The Marx doctrine is the guiding ideology of the Communist Party and the socialist cause Chinese construction, along with the development of socialism and the continuation of the guiding ideology of the formation of a lot of Chinese practice, and the construction of socialist culture is a kind of theory of Marx China theory achievement performance. After the founding of new China, Marx's cultural theory has become the theoretical basis of Zedong Mao thought culture concept, and on the basis of the actual development of our country's integration of more new content, the formation of the socialist cultural theory Chinese characteristics: such as the new requirements of Xiaoping Deng theory to the spiritual civilization construction, and Zemin Jiang, Jintao Hu put 
forward the "Three Represents" the important thought and Scientific Outlook on Development important discuss, these theoretical results continue to guide the further development of China's cultural industry, and the process of socialist cultural construction plays an important role in guiding.

\section{Part Two an Analysis of the Guiding Strategy of Marx's Cultural Thought on the Development of China's Cultural Industry}

\section{Implementing the Innovation of Cultural Industry Policy and Related Laws}

Although the development of cultural industry in China has achieved outstanding achievements, it still finds problems in its development mode, industrial policy and institutional management in comparison with western developed countries. Therefore, for China's cultural industry, it should resolutely implement the Scientific Outlook on Development on the basis of the current context of globalization and cultural industry development trend analysis, the market demand and consumption potential were evaluated to determine the innovation policy of cultural industry and management system, add more elements to keep pace with the times which will not in line with the current industrial development so as to exclude parts, and the development of cultural industry plays an effective role in guiding.

First of all, China's cultural industry in the concept has not too much emphasis on the development of the market demand and the consciousness of spiritual civilization construction, but rather focus on the formation of larger; the government should guide the cultural industry to form a new cultural concept, innovate some outdated be inopportune or inappropriate industry policy and system in part. And try to realize the cultural industry through policy guidance and legal instruments, so that it can actively respond to the current open international environment down since the conflict of Western values and the influx of bad ideas.

Secondly, for the laws related to the development of cultural industry, we should take full consideration of the status of China's industrial development and draw lessons from the advanced industrial mode abroad, so as to make innovations in law. The government should improve the sensitivity of the culture of law, combined with the actual increase in some details of the law or that is absent in the law perfect part, such as the copyright problem for more comprehensive discussion and research, and through the improvement of the legal implementation of the cultural industry to improve the market environment, and the external dynamic of industry regulation, and to promote the comprehensive development of the cultural industry.

\section{Establishing the Correct Policy for the Development of Cultural Industry}

Under the present complex cultural background, the development of China's cultural industry needs specific and correct guiding principles.

First of all, it should realize the competitiveness of China's cultural industry to improve the technology content of the cultural industry, strengthen the technical level, and improve the brand effect of related enterprises with reversing the traditional sense of China's cultural products and low level of awareness to enhance social influence; at the same time, the relevant enterprises should try to take some good practice to add to the product through the wisdom of integration, the process of development of human society, such as the excellent traditional culture to improve the products in the international market recognition, so that China's cultural industry can get more results from other countries favor with the realization of foreign export of our country culture.

Secondly, the cultural industry should pay attention to the introduction and cultivation of talents. At present, people are engaged in cultural industry in China lack of advanced talents with good technological accumulation, cultural understanding and market competition knowledge. Therefore, the cultural industry should have targeted talents introduction. On the one hand, it should pay attention to the importance of talents, improve the cultural industry practitioners salary, let employees have higher enthusiasm; on the other hand, and they should realize the comprehensive source of talent, innovative talents comprehensive good comprehensive quality and ability of many colleges and universities, thus using the resource allocation function of market the construction of China's cultural talent market, the University's personnel training work and the talent introduction 
work better together; and the society also has a lot of the staff, many of whom are prominent ability, so it should improve the way of personnel selection, and try to improve social artists, practitioners of the innovation ability to improve the whole industry quality; at the same time, the outstanding talents of cultural industry in the developed countries also should keep proper attention, through some policy support and treatment focus attract some excellent talents to work in China or start businesses, so as to improve the overall strength of the industry and provide objective conditions for training employees.

In addition, the state and the government should also clear talent important value in the development of cultural industry to recognize the talents in the development of cultural industry can contribute to the power of the "talent strategy" as one of the important guideline for the development of cultural industry to provide protection for culture industry development.

\section{Perfecting the Market System of Cultural Industry}

First of all, the government should promote the integration of culture and technology in the cultural industry by strengthening the construction of technical market and rich technology exchange way to let the domestic technological achievements output to the cultural industry, the cultural industry helps improve the competitiveness of products, and has a good potential demand in the market. In addition, it can focus on the application of technology in the cultural industry, find a balance between market demand and enterprise technology level, so as to enhance the competitiveness of the related products in the cultural industry.

Secondly, the government should help the cultural industry to a certain extent. The large-scale cultural enterprises should help improve the means of financing to improve the degree of internationalization of enterprises by encouraging foreign investment and other means, and through internal capital and private capital to increase the degree of absorption of rich investment theme. For small and medium sized enterprise culture, it should establish perfect financing information exchange platform, and help small cultural enterprises to have the higher financing capacity, and through some special fund or project for some enterprises to encourage and support, let the whole cultural industry can form the strong market competition background.

Finally, the government should ensure the basic construction of spiritual civilization of our country, through to guide the market to form a reasonable cultural needs to produce cultural consumption, and promote the progress of China's cultural industry; at the same time, it should adopt some means to avoid large-scale cultural enterprises monopoly phenomenon, and provide greater living space for small and medium-sized companies some start-ups to indirectly protect comprehensive cultural business.

\section{Conclusion}

To sum up, Marx's cultural thought has profound theoretical guiding significance for the development of China's cultural industry. For the development of China's cultural enterprises, it should be based on the full understanding of Marx's thought of culture connotation from the culture of innovation policy to guarantee industry environment and clear development policy and improve the market system in four aspects together to provide an inexhaustible motive force for the development of Chinese cultural industry escort for the construction of socialist spiritual civilization.

\section{Reference}

[1] Shaochun Liang. On Marx's view of cultural industry and its contemporary value[J].Journal of Huaihua University,2016,35(10):46-49.

[2] Hanjie Li, Shusong Wang.The guiding significance of Marx's theory of spiritual production to the development of China's cultural industry[J].Theoretical Observation,2016(09):12-13.

[3] Xiaoqun Huang. Marx's theory of art production and its enlightenment to the development of cultural industry[D].Beijing University of Chemical Technology,2016.

[4] Hua Ji. A study of the culture view of Marx and the development of China's cultural industry[J].New West (Theoretical Edition),2016(21):3+17. 